\title{
The implication of Energy on Nigeria's Economy: Case Study of Crude Oil Energy Source
}

\author{
Otitigbe F. E. \\ Department of Petroleum Engineering, Delta State University, Abraka, Oleh Campus, Nigeria \\ Corresponding Author: *fotitigbe@yahoo.com
}

https://doi.org/10.36263/nijest.2021.02.0302

\begin{abstract}
The shortfall in crude oil production, the major source of energy supply and revenue generation in Nigeria, affects all spheres of activities in the country. Activities like politics, economic, budgeting, infrastructural development, the standard of living, and foreign exchange reserve. Therefore, it is imperative to address the implication of energy (crude oil source) on the economy of Nigeria. Hence, a linear regression analysis was used and by first creating a link between oil production (main energy source) and oil earnings (economy) to establish a relationship upon which socialpolitical factors such as the organization of petroleum exporting countries (OPEC), civil disturbance, flexible regulating framework, infrastructural services, community inclusion for equitable sharing of benefit, and Niger Delta development commission are used as check and balance on oil production and oil earning and their implications on the Nigeria economy. By way of calibration, the paper examines the amount of oil per barrel needed to be produced in a year that would guarantee an increase in oil earnings in Nigeria. The data used for this analysis were collected from the central bank of Nigeria (CBN) statistic bulletin on crude oil production and total earning in Nigeria between 1980 to 1999. The paper also suggests measures that would enhance the increase in the production of oil from which the country would be able to earn more revenue. The result shows that increasing oil production will simultaneously increase earnings from oil and, consequently, overhaul the various activities such as economy, infrastructural development, health, education sectors, and living standard of the citizen.
\end{abstract}

Keywords: Crude oil, Poverty, Revenue, Energy, Economy, CBN

\subsection{Introduction}

Nigeria is well endowed with a variety of energy sources which are grouped into conventional and non-conventional energy sources. The conventional sources of energy include crude oil, natural gas, coal, nuclear, bitumen, and hydroelectricity, while the non-conventional sources include geothermal energy, biomass, oil shale, and sand (Iwayemi, 1998; Zou et al., 2016).

Crude oil, which is the most dominant source of energy in Nigeria (Titilayo, 2020; Wu et al., 2019), was discovered in 1956 with an initial output of 51,000 barrels per day (BPD) (Akinosho, 1998). By the 1970s, a sporadic increase in outputs and earnings was witnessed, thus tagging the period the oil boom era, with crude oil constituting about $70 \%$ of the total commercial energy consumption and providing more than $90 \%$ of Nigeria's foreign exchange income (Okonkwo, 1998). In 1999, the crude oil output was 778,900 barrels while the earning was N 724,422.5 million (Central Bank of Nigeria, 1999).

However, despite the large production and its huge foreign exchange earnings, crude oil production and earnings have been very erratic in Nigeria because of the fluctuations in the price of crude oil at the world market, frequent breakdown of the petroleum refineries, and incessant stoppage of oil production caused by riots, agitation, politics and communal crisis in the oil-producing areas (Seplat Petroleum Development Company Plc, 2019; Index Mundi, 2014). 
Judging from the above scenario, it is assumed that if the government can increase its crude oil output and find the solution to the incessant breakdown of the refineries and socio-political instabilities that cause shortages, there would be an increase in oil production and oil earnings in Nigeria. The required quantity of crude oil that would consequently increase government revenue through oil earnings is, therefore, the main concern of this paper.

\subsection{Conceptual issues: energy, oil production, and oil earnings}

Kashkari (1975) cited in Ayodele (1998) conceptualizes energy as the capacity to perform or do things. This capacity comes from the various sources of energy, which are grouped into convectional and non-convectional energy sources. The conventional energy sources are also grouped into renewable energy (such as hydro-electricity and wood fuels), and non-renewable energy (such as coal, lignite, crude oil, etc.); and non-conventional sources include geothermal energy, biomass, oil shale, and sand (see also Iwayemi, 1998).

However, of all the sources of energy, crude oil is the most dominant and important source of energy in Nigeria (Hawkins, 1995). Emphasizing its importance to economic development, Mcphail (2000) argues that crude oil makes a significant contribution to the economic development of an endowed country because it generates sizeable revenues, creates jobs and business opportunities, and brings new roads and access to water and power to the isolated rural areas in which they are typically located. Besides, they have the potential to stimulate economic growth, reduce poverty, and raise living standards (Ebegbulemet al., 2013).

Ayodele (1998) also opines that apart from serving as a pillar of wealth creation (export and revenue earnings; contribution to the GDP; employment-generating, etc.), it is also the nucleus of operations and the engine of growth for all the sectors of the Nigerian economy (Okonkwo,1998; Abojeet al., 2016). Thus asserts that revenue from crude oil accounts for over $70 \%$ of Nigeria's national income, and in 1999 alone accounted for over 90\% of foreign exchange earnings of the country, which translates to $76 \%$ ( $\$ 724,422.5 \mathrm{~m}$ ) of the total federally collected revenue (see also Central Bank of Nigeria 1999). Nwokedi (1992) also corroborated this importance when he says that enormous revenue earns from oil forms the basis of development expenditure of Nigeria (Cited by Ojinnaka, 1998).

Drawing instances from Equatorial Guinea, The News Magazine (2002) cited the case of Malabo, the capital city of Equatorial Guinea, which through oil earnings the city, has witnessed transformation in office buildings, hotels and banking activities. Besides, the country's annual per capita GDP rose from $\$ 500$ in 1993 to $\$ 2000$ in the year 2002 (Maji, 2015).

The Chad Republic that is categorized as a poor country by the World Bank will soon benefit from crude oil (Edomahet al., 2016). The country is expected to earn billions of dollars with which it is expected to improve health, education, and infrastructural services critical to an improvement in the standard of living of its people. McPhail (2002) also cited the case of Papua New Guinea where the schools, health clinics, water supply, and sanitation have benefited largely from crude oil earnings.

\subsection{Trends of oil output and earnings in Nigeria}

Since the 1980s, crude oil output has followed a fluctuating trend even though oil has consistently contributed over $60 \%$ of the total federally collected revenue. As indicated in Table 1 from 1980 to 1989, total oil production has witnessed a series of fluctuations declining from 760,117 barrels in 1980 to 625,908 barrels in 1989 . This decline in output is due partly to OPEC output control measures because of the global oil glut as well as civil disturbances in the oil-producing areas which are induced by environmental damages such as erosion, inundation, denegation, increased Stalinization of surface and groundwater; and health risk associated with vector-borne diseases (Ayodele, 1998; Titilayo, 2020; Adewuji et al., 2020). 
However, in the 1990s, crude oil production witnessed a continuous increase except for 1993 and 1994 when there was a decline in oil production induced by the political crisis witnessed in the country (Thombs, 2019; Oyekanmi, 2020).

These fluctuations in output also affect the total oil earnings. For instance, the percentage contribution of crude oil to total federally collected revenue declined from $81.0 \%$ in 1980 to $72.6 \%$ in 1989 . This decline can be linked to the fluctuations in the prices of oil at the world market experienced then (The Global Economic.com. 2020). The invasion of Kuwait by Iraq in the early 1990s brought a brief near doubling in the nominal price of oil during the third quarter of 1990 which increases oil earnings in the oil-producing countries including Nigeria (Killick, 1993; Steven, 2019; Pistelli, 2020). While the decline witnessed in oil earnings in 1998 was attributed to the rise in OPEC crude oil supplies and the impact of mild winter associated with the EL Nino phenomenal on the major oil-consuming countries which exerted downward pressure on oil prices in 1998 (Iwayemi, 1998; Chukwuebuka et al., 2021). Apart from these problems, the increase in oil production has continued to increase oil earnings (Central Bank of Nigeria, 2015).

Table 1: Crude oil production and total oil earning in Nigeria

\begin{tabular}{|c|c|c|c|c|}
\hline Year & $\begin{array}{l}\text { Production } \\
\text { (Million barrel) }\end{array}$ & Total Fed Revenue & $\begin{array}{l}\begin{array}{l}\text { Total Oil Earnings } \\
\text { (Million) }\end{array} \\
\end{array}$ & Ratio \\
\hline 1980 & 760117 & 15233.5 & 12353.3 & 81.09 \\
\hline 1981 & 525291 & 13290.5 & 8564.4 & 64.44 \\
\hline 1982 & 470638 & 11433.7 & 7814.9 & 68.35 \\
\hline 1983 & 450961 & 10508.7 & 7253.0 & 69.02 \\
\hline 1984 & 507487 & 11253.3 & 8269.2 & 73.48 \\
\hline 1985 & 547088 & 15050.4 & 10923.7 & 72.58 \\
\hline 1986 & 535929 & 12595.8 & 8107.3 & 64.36 \\
\hline 1987 & 483269 & 25380.6 & 19027.0 & 74.97 \\
\hline 1988 & 529602 & 27596.7 & 19831.7 & 71.86 \\
\hline 1989 & 625908 & 53870.4 & 39130.5 & 72.64 \\
\hline 1990 & 660559 & 98102.4 & 7188701 & 73.28 \\
\hline 1991 & 689850 & 100991.6 & 82666.4 & 81.85 \\
\hline 1992 & 711340 & 190453.3 & 164078.1 & 86.15 \\
\hline 1993 & 691400 & 192769.4 & 162102.4 & 84.09 \\
\hline 1994 & 696190 & 201910.8 & 160192.4 & 79.34 \\
\hline 1995 & 715400 & 459987.3 & 324547.6 & 70.56 \\
\hline 1996 & 740190 & 520190.2 & 408783.0 & 78.58 \\
\hline 1997 & 759710 & 585811.1 & 416811.1 & 71.52 \\
\hline 1998 & 776190 & 463608.8 & 324311.2 & 69.95 \\
\hline 1999 & 778900 & 949187.9 & 724422.5 & 76.32 \\
\hline
\end{tabular}

Source: Central Bank of Nigeria statistic bulletin (1980-1999)

\subsection{Methodology}

\subsection{Data source}

Time series data for the period 1980-1999 on crude oil production and crude oil earnings in Nigeria were used (Statista, 2020). The data were obtained from the Central Bank of Nigeria (CBN) Statistical Bulletin for the year 1999 (Momodu, 2017).

\subsection{Linear regression method}

The linear regression method is an elementary and commonly used method for predicting events of occurrence (predictive analysis). The general ideal examines two occurring events such as:

1. Does a set of independent (predictor) variables do a good job in predicting a dependent variable (outcome)

2. which variables, in particular, are important in predicting the dependent variable, and how will the magnitude on the sign of beta displayed by the independent variable impact the dependent variable.

Generally, regression analysis is used to ascertain the ability of the effect that the independent variable(s) have on a dependent variable and as well predict trends and future values such as 
determining a point estimates, which takes the form of a question like "what will the price of crude oil be in a month or year to come".

\subsubsection{Types of linear regression}

There are simple and multiple types of linear regression. The simple linear regression simply means a variance involving one dependent variable (interval or ratio) and one independent variable (interval or ratio or dichotomous) while the multiple linear regression involves one dependent variable (interval or ratio) and two independent variables (interval or ratio or dichotomous).

Multiple linear regression is a statistical method that involves two or more independent variables to predict the outcome of a dependent variable, and this helps analysts to determine the variation of the model and the relative contributions of each independent variable in the total variance.

In addition, is used to determine a mathematical relationship among several random variables. In order words, it evaluates how various independent variables affirmed a relationship with one dependent variable. Thus, once each independent (variable) is gotten to predict the variable (factor) and then is used to create a prediction on the level of effect the independent variable has on the dependent variable.

The multiple linear regression is mathematically expressed as:

$y_{i}=\beta_{0}+\beta_{1 x i 1}+\beta_{2 x i 2} \ldots \beta_{\text {pxip }}+\epsilon$

Where, $y_{i}=$ dependent (predicted) variable

$\beta_{0}=\mathrm{y}$-intercept (i.e. the value of $\mathrm{y}$ when both $x_{i 1}$ and $x_{i 2}$ are zero).

$\beta_{1}$ and $\beta_{2}=$ regression coefficients representing the changes in $x_{i 1}$ and $x_{i 2}$ respectively.

$\beta_{p}=$ slope coefficient for each independent variable

$\epsilon=$ model random error (residual term).

For this research paper, the multiple linear regression method was used oil production and oil earning data. Courtesy of Nigeria. Central Bank of Nigeria statistic bulletin (1980-1999) and have established this link, the model is therefore formulated as shown in Equations 2 and 3.

$O P=f(O E, S P F)$

With a linear relationship such as:

$O P=\beta_{0}+\beta_{1} O E+\beta_{2} S P F=U+a+0$

Where,

SPF $=$ socio-political factors that determine the amount of oil production and oil earnings. Note that those factors are interactions variables that influence oil productions and earnings in Nigeria.

ao $=$ intercept

$\mathrm{a}$, and $\mathrm{o}=$ the estimation parameters

$\mathrm{U}=$ disturbance term.

$\mathrm{OP}=$ oil production

$\mathrm{OE}=$ oil earning

The a-prior expectations between dependant variable (oil productions, OP) and the independent variables (oil earnings and socio-political factors, SPF) are can be expressed in a differential equation as:

$$
\begin{aligned}
& \frac{\partial O P}{\partial O E}>0 \\
& \frac{\partial O P}{\partial S P f}>0
\end{aligned}
$$


Equation 2, mathematically mean the oil production (OP) is said to be a function of oil earning (OE) and social-political factor (SPF) and are independent variables while the dependent variable is the oil production, and have direct implications on oil production and in turn on the economy.

Knowing investment in the petroleum industry is the sole economic benefit, and if produced without sale, no earning would be made, and production will be reduced since the marketability is low or not there.

On the other hand, certain ingredients such as crude oil price reduction, quota system, war/crisis, or political instability are all social-political factors that also have negative implications on oil production and the economy as oil exploration and production activities can take place in crisis area (Sovacool, 2016; Kah, 2018; Greenstone et al., 2019; World Bank, 2020).

Equation 4 expresses the direct proportionality between oil production (OP), and oil earning (OE) and it means an increase in oil production increases oil earning, while Equation 5 has a more direct implication on oil production as in the case of a war turn area, where oil activity is stopped, the supplied quota would be shared among the other oil-producing members and thereby increase oil productions in their respective countries.

These indicate that as the quantity of oil production increases, the amount earned from oil will also increase, while a stable socio-political situation in the country will lead to an increase in oil production. The tests are conducted at a 5\% level of significance.

\subsection{Results and Discussions}

The results of regression analysis are presented in Table 2.

Table 2: Regression results of oil production and oil earnings in Nigeria

\begin{tabular}{lc}
\hline Variables & Co-efficient Estimates \\
\hline Intercept & 591139 \\
$(\mathrm{t})$ & $(9.03)$ \\
$\mathrm{OE}$ & 0.43 \\
$(0$ & $(2-42)$ \\
$\mathrm{SPF}$ & -72142.4 \\
$(0$ & $(-1.03)$ \\
$\mathrm{R}^{2}$ & 0.60 \\
$\mathrm{~F}$ & 4.98 \\
\hline \multicolumn{2}{c}{ (Source: Author's Computation) }
\end{tabular}

Table 2 shows the regression result of oil production and oil earnings in Nigeria. The R-square $\left(R^{2}\right)$ is also called the coefficient of determination and it established the worthiness of the model by its low or high value obtained. The increased percentage value of $\mathrm{R}$-square of sixty percent $(60 \%)$, indicates a fairly good model as a result of an increase in the variance of the model due to the addition of the independent variable to the linear regression model.

The five percent (5\%) level of significant point-estimate, for f-statistic, shows that the model is useful in determining the implications of oil production and oil earning on the economy in Nigeria because the computed $F$-statistic which is 4.98 , is greater than the tabulated value at 3.94.

And for the independent variables, the $t$-test at a five (5\%) level of significance clearly shows that oil production is directly related to oil earnings, and thus, satisfying our prior expectations. The negative sign that appears on the independent factor (variable), social-political factor (SPF) is an indication that the margin between oil production and oil earning is insignificant as a result of the elements that promote a work-free environment such as crisis, policies, oil quota system and war never occur as an attempt were given immediate attention.

Given the results obtained from the model, the calibration analysis of oil production on oil earnings in Nigeria is presented thus: 
Since our concern is to find out the implication of oil production on oil earnings, we, therefore, hold SPF constant.

Equation (6) then becomes:

$O P=591139+0.430 E$

The appropriate $100 \%$ prediction interval for $\mathrm{OP}$ when $\mathrm{OE}=\mathrm{OP}$ is $\mathrm{OP} \pm \operatorname{tdj} \mathrm{SN}^{\wedge}$ where the distribution of $t$ is based on (n-2) degree of freedom. The results of the calibration of the implication of oil production on oil earnings at 5, 10, 15, and 20 percent increases on an annual average of 632,800 barrels of oil are presented in columns 3 and 4 of Table 3.

Table 3: Calibration results of implications on oil production and oil earnings.

\begin{tabular}{llllll}
\hline Calibration Percentage & $\begin{array}{l}\text { Mean } \\
\text { Value(632800 } \\
\text { Annum }\end{array}$ & $\begin{array}{r}\text { Production } \\
\text { Barrels) }\end{array}$ & $\begin{array}{l}\text { Perel of Oil Production } \\
\text { Value (Barrels) }\end{array}$ & $\begin{array}{l}\text { Point Million) } \\
\text { Prediction Interval } \\
\text { Earning }\end{array}$ & $\begin{array}{l}\text { of } \\
\text { in Oil }\end{array}$ \\
\hline $5 \%$ & 664,440 & & $876,848.2$ & $876,838.3-896,858.1$ \\
$10 \%$ & 696,080 & & $890,453.4$ & $890,443.5-890,463.3$ \\
$15 \%$ & 727,720 & & $904,055.6$ & $904,045.7-904,065.5$ \\
$20 \%$ & 759,360 & $917,663$. & $917,653.9-917,673.7$ \\
\hline
\end{tabular}

(Source: Author's Computation)

Table 3clearly displayed the calibration results of the oil production and oil earnings. The respective calibration percentage and production values per annum are shown in columns 1 and 2 with an average mean of 632,800 barrels of oil production per annum.

In Table 3, the general outlook as observed shows a gradual and progressive increase on all the data values in the entire column.

This is as a result of the minimal effects received from actions of the elements of independent factor which are insignificant to the oil production and oil earnings.

\subsection{Conclusions}

The multiple linear regression (MLR) method applied in the evaluation of the implication of oil production on oil earning using predictors factor shows accurate results and the method is good.

The result justifies the point-estimate accuracies of any range of oil production data and for any period of years of interest to be able to project future implications of oil production and oil earning on the economy in Nigeria.

The simultaneous increase in oil production and oil earning is made possible through the prompt response to elements of independent variables (social-political factor) that would have undermined the smooth operations of crude oil productions.

Therefore, the multiple linear regression method is recommended for use by government, companies, and public individuals for accurate analysis and future prediction of occurred and un-occurred events.

\section{References}

Aboje, A., Abdulfatai, J., Saka, Ambali, A. and Onyeji, L. (2016).Economics and Environmental impacts of oil exploration and exploitation in Nigeria.Research Gate. https://www.researchgate.net/publication/303865317. pp. 251.

Adewuyi, O. B., Kiptoo, M. K. and Afolayan, A. F. (2020).Challenges and the prospect of Nigeria's sustainable energy transition.Energy Rep 6, pp. 993-1009.

Akinosho, T. (1998).Petroleum in Nigeria's Energy Crisis.Central Bank of Nigeria Bulletin,22(4), pp. $25-29$ 
Ayodele, S. A. (1998). Energy Crisis in Nigeria: The Case of Electric Energy Market. CentralBank of NigeriaBulletin, 22(4), pp. 19-21.

Central Bank of Nigeria CBN (1999).Statistical Bulletin, Lagos: CBN.

Central Bank of Nigeria (CBN) (2015). Analysis of energy market conditions in Nigeria. Occasional paper no. 55 .

Chukweuebuka, O., Madu, C., Ajaero, C., Ibekwe, J., Bebenimibo, H. and Nzekwe, C. (2021). Moving beyond fossil fuel in an oil-exporting and emerging economy.AIMS Energy. 9(2), pp 381.

Ebegbulem, J. C., Ekpe, D. and Adejumo, T. O. (2013). Oil exploration and poverty in the Niger Delta region of Nigeria: Acritical analysis. International Journal of Business and Social Science, 4(3), p. 2.

Edomah, N., Foulds, C. and Jones, A. (2016). Energy transition in Nigeria: The evolution of energy infrastructure provision (1800-2015). Energy 9, p. 484.

Greenstone, M. and Reguant, N. (2019). Evidence paper. International growth center (IGC), London School of economic and political science, Houghton Street, London. WC 2A 2AE, 1-44.

Hawkins, J. M. (1995). (ed). The Oxford Mini-reference Dictionary. New York: Oxford University Press.

Index Mundi, (2014).Nigeria crude oil production and consumption by year (Thousand barrels per day).Available from: $\quad$ https://www.indexmundi.com/energy/?country=ng\& graph $=$ production + consumption .

Iwayemi, A. (1998). Energy Sector Development in Africa. The "African Development Bank Economic Research Papers No.43.

Kah, M. (2018). Electric motor and the impact on oil demand: Why forecasts differ, Center on Global Energy Policy, Columbia. SIPA. pp 1-15

Kashkari (1975).Economic Stabilization Act. 1975: The Nigerian Journal of Political Economic. The University of Lagos. Vol.2, No. 2:3

Killick, T. (1993). The Adaptive Economy: Adjustment Policies in Small, Low- income countries.The World Bank Finance and Development, 37(4), pp. 46-49.

Maji, I. K. (2015). Does clean energy contribute to economic growth? Evidence from Nigeria. Energy Rep. 1, pp. 145-150.

McPhail, K. (2000). How Oil and Mining Projects can Contribute to Development. IMF/World Bank EDI Development Series No. 400/058.

Momodu, I. K. (2017).The impact on the economic growth of Nigeria oil dependency. Master's project presented to the institute of social studies, Hague, Netherland. P.O.Box 29776, 2502 LT.

Nwokedi (1992) Energy Options in the Industrialization and Development Process of theNation, What Role for Coal. CBN Bulletin, 22(4), p. 30.

Ojinnaka, I. P. (1998). Energy Crisis in Nigeria: The Role of Natural Gas. CBN Bulletin, 22(4), pp. 812.

Okonkwo, W. I. (1998). Energy Crisis in Nigeria: The Role of Natural Gas. CBN Bulletin, 22(4), pp. $44-47$ 
Oyekanmi, S. (2020). Updated: Nigeria's economy grows by $2.27 \%$ in 2019 , post highest quarterly growth since the 2016 recession. Available from: https://nairametrices.com/2020/02/24/nigeriaeconomy-grows-by-2-27-post-highest-quarterly-growth-since-2016-recession/.

Pistelli, L. (2020). Addressing Africa energy dilemma. In: Hafer and Tagliapieta (eds), the geopolitics of the global energy transition. Lecture Notes in Energy 73, pp. 151-174.

Seplat Petroleum Development Company Plc. (2019). Nigeria Energy Transformation: Special feature, Seplat Petroleum Development Company Plc Annual Report and Accounts. 44-51.

Sovacool, B. K. (2016). The history and politics of energy transition: Comparing contested views and finding common ground. United Nation University, World Institute for development economic research, WIDERworking paper 2016/81, Helsinki, Finland.

Statista, (2020). Oil production in Nigeria from 1998 to 2019. Available from: http://www.statista.com/statistics/265195 oil-production-in-Nigeria-barrels-per-day/.

Steven, P. (2019). Theo geopolitical implication of future oil demand: Paradigm Shift. Research Paper: TheRoyal Institute of International Affairs: Chatham House. Pp 1-42.

The Global Economic.com. (2020). Nigeria foreign direct investment, percentage of GDP, Chart. Available from: https//www.theglobaleconomy.com/Nigeria/ForeignDirect Investment/.

The News Magazine (2002). Black Gold. Lagos: The News Magazine. Vol.19. No. 19.

Thombs, R. P. (2019). When democracy meets energy transitions: A typology of social power and energy system scale.Energy research Social Science. 52: 159-168

Titilayo, S. (2019).The impact of oil theft on social and economic development in the Niger Delta. Global journal of social sciences. Vol. 19. pp. 1.

World Bank (2017). Nigeria Bi-annual Economic update: Fragile economy. The world bank IBRDIDA No.1-April 2017.

World Bank (2020). Nigeria's Economy faced worse recession in four decades says a new world bank report, Available from: https://www.worldbank.org/en/news/press-release/2020/06/25/nigeriaeconomy-faces-worstrecession-in-four-decades-say-new-world bank-report.

Wu, X. F. and Chen, G. O. (2019). Global overview of crude oil use: From source to sink through inter regional trade. Energy Policy. 128: 476-486.

Zou, C., Zhao, Q. and Zhang, G. (2016). Energy revolution: from fossil fuel energy era to a new energy era.

Cite this article as:

Otitigbe F. E. 2021. The implication of Energy on Nigeria's Economy: Case Study of Crude Oil Energy Source. Nigerian Journal of Environmental Sciences and Technology, 5(2), pp. 468-475. https://doi.org/10.36263/nijest.2021.02.0302 